Putri Susanti: Tema dan Kekhasan Bahasa dalam Teks Segala Cerita Anak Sekula

\title{
TEMA DAN KEKHASAN BAHASA DALAM TEKS SEGALA CERITA ANAK SEKULA
}

The Themes and the Uniqueness of the Malay Language in Segala Cerita Anak Sekula Text

\author{
Putri Susanti \\ Lembaga Bimbingan Belajar Salemba Group \\ Jalan Komjen Pol. M. Jasin No. 62, Kelapa Dua, Depok, Jawa Barat, Indonesia \\ Pos-el: po3try cutey@hotmail.com
}

Naskah masuk: 20 Mei 2020, disetujui: 24 Juni 2020, revisi akhir: 27 Juni 2020

\begin{abstract}
Abstrak
Penelitian ini muncul dari penelusuran penulis terhadap naskah Melayu yang berjudul Segala Cerita Anak Sekula (SCAS), sebuah naskah yang dapat digolongkan sebagai hikayat dengan tujuh cerita tentang hewan (fabel). Dari judul naskah tersebut, penulis akan menganalisis tema cerita dan kekhasan bahasa Melayu karena ada kemungkinan naskah ini dijadikan bahan ajar untuk anak sekolah. Sesuai dengan hal tersebut, tujuan dari penelitian ini adalah menunjukkan kekhasan bahasa dan tema cerita dalam SCAS, serta mengidentifikasikan secara tematik bahan bacaan anak-anak sekolah pada masa-masa akhir abad ke-19. Metode yang digunakan dalam penelitian ini adalah pendekatan struktural dalam penyimpulan tema terkait hubungannya dengan tokoh, latar, dan alur. Dari penelitian ini, diperoleh paparan kekhasan bahasa yang tidak menyulitkan penulis dalam membaca naskah ini dan tema-tema cerita yang muncul dalam naskah SCAS.
\end{abstract}

Kata kunci: SCAS, kekhasan bahasa, teks, dan tema

\begin{abstract}
This research emerged from the author's search to the Malay Manuscript that titled Segala Cerita Anak Sekula (SCAS), a text that can be classified as a saga with seven stories about animals (fables). From the title of the manuscript, author will analyze the theme of the story and the uniqueness of the Malay language because there is a possibility that this script will be used as teaching material for school children. According to, the purpose of this study is to show the uniqueness of the language and story themes in SCAS, and to identify thematically the reading material of school children in the late 19th century. The method used in this study is a structural approach in the inference of themes related to the relationship with figures, settings, and plot. From this study, it was obtained exposure to language uniqueness that did not complicate the writer in reading this manuscript and the themes of the stories that appeared in the SCAS manuscript.
\end{abstract}

Keywords: SCAS, language specifications, text, and theme.

\section{Pendahuluan}

Bangsa Indonesia memiliki warisan budaya yang sangat kaya dan beragam yang diturunkan dari generasi ke generasi. Warisan tersebut tidak hanya berupa tradisi lisan, tetapi juga tradisi tulis yang terekam dalam berbagai bentuk naskah. Jumsari Jusuf (1982), seperti yang dikutip oleh Sri Wulan Rujiati Mulyadi, menyebutkan naskah tersebut ditulis pada kertas daluwang (kertas yang dibuat dengan kayu sebagai campuran), daun lontar (disebut lontar), daun nipah (untuk menulis naskah Sunda), kulit kayu (pustaha; kulit kayu yang dilipat seperti akordeon, digunakan pada naskah Batak), bambu, rotan, tonggak batu, lempengan tembaga atau emas (prasasti). Menurut Albertine Gaur (1979), naskah juga ditulis pada daun palma, batu bata yang terbuat dari tanah liat (claybricks), papirus, bahan linen, velum, sutera, dan perkamen (Mulyadi, 1994:44). Seiring dengan datangnya orang asing ke Indonesia, naskah mulai ditulis di atas kertas. Bahan 
yang digunakan untuk menulis teks adalah arang dan tinta. Naskah tersebut ditulis dalam bahasa dan aksara yang bermacammacam serta diperbanyak dengan cara disalin. Salah satunya adalah naskah berbahasa Melayu yang beraksara ArabMelayu atau lebih dikenal dengan aksara Jawi. Huruf Jawi ini paling banyak ditemukan dalam naskah Melayu klasik (Ikram, 1997:38).

Naskah Melayu yang tersebar dan tersimpan di tangan kolektor belum diketahui jumlahnya dengan pasti. Berdasarkan daftar dari Chambert-Loir (Loir, 1999:131-171), naskah tersebut tersimpan di 30 negara berupa hikayat, syair, surat, surat jalan, arsip, dan dokumen penting berbahasa Melayu. Hal ini menunjukkan kekayaan khasanah kesusastraan Melayu tidak hanya dalam hal jumlah, tetapi juga dalam hal isi. Isi yang terkandung dalam naskah Melayu, misalnya sejarah bangsa, kehidupan masyarakat di masa lampau, dan hubungan diplomatik yang terjalin antara kerajaan di Nusantara dengan bangsa lain.

Naskah Melayu dibedakan atas ragam prosa dan puisi (Sudjiman, 1995:17). Judul naskah berbentuk prosa biasanya diawali dengan hikayat, misalnya Hikayat Aceh, Hikayat Bikrama Sakti, Hikayat Purusara. Ada pula judul naskah yang diawali dengan sejarah, misalnya Sejarah Melayu, Sejarah Raja-raja Riau, dan terdapat pula naskah yang diawali dengan undang-undang, misalnya Undang-undang Melaka, Undangundang Laut. Setelah melakukan penelusuran di katalogus, penulis menemukan sebuah naskah yang judulnya tidak diawali dengan kata hikayat, sejarah, ataupun undang-undang. Naskah ini berjudul Segala Cerita Anak Sekula (selanjutnya akan disebut SCAS). Berdasarkan judulnya, penulis menduga SCAS adalah naskah yang memuat cerita untuk anak-anak sekolah. Dugaan ini menimbul ketertarikan penulis menggali lebih dalam tentang tema yang muncul dalam SCAS sehingga naskah ini dijadikan sumber bahan bacaan pada akhir abad ke19. Tambahan pula, ada beberapa karakter bahasa Melayu yang khas muncul di dalam teks ini.

Berdasarkan dugaan tersebut, penulis bermaksud mencari tema cerita yang muncul dalam SCAS sehingga naskah ini cocok dijadikan bahan ajar pada akhir abad ke-19. Selain itu, penulis juga ingin menunjukkan kekhasan bahasa yang muncul dalam teks SCAS guna memudahkan pembaca menggali isi teks. Hal ini disebabkan oleh perubahan yang terlihat jelas antara bahasa Indonesia dan bahasa Melayu.

Untuk melakukan analisis tema, penulis menggunakan pendekatan stuktural dalam karya sastra. Menurut Stanton (1965) dan Kenny (1966), tema adalah makna yang terkandung dalam sebuah cerita. Akan tetapi, di dalam sebuah cerita terdapat banyak makna sehingga kita kesulitan menentukan makna mana yang dapat dinyatakan sebagai tema (Nurgiyantoro, 1995:67). Berbeda dengan Stanton dan Kenny, Panuti Sudjiman mendefinisikan tema sebagai gagasan yang mendasari karya sastra. Hal ini membuat karya lebih penting daripada sekadar bacaan hiburan. Tema cerita disampaikan secara eksplisit dan implisit. Tema yang dinyatakan secara eksplisit terlihat jelas pada judul atau dinyatakan secara simbolik, sedangkan tema yang implisit tidak ditampilkan dengan jelas dalam teks (tersirat) (Sudjiman, 1988:50-51).

Tema dalam karya sastra merupakan salah satu unsur pembangun cerita. Eksistensi tema sangat bergantung pada unsur pembangun lainnya (Nurgiyantoro, 1995:74). Tema tidak mudah ditemukan, diperlukan pembacaan yang tekun dan cermat pada karya sastra. Hal tersebut dapat ditemukan dalam pelukisan latar, tersirat dalam lakuan tokoh, atau dalam penokohan. Tema dapat menjadi faktor yang menghubungkan peristiwa dalam alur. Selain itu, tema dapat pula terwujud dalam dialog antartokoh, misalnya dialog Tuti dalam Layar Terkembang karya Sutan Takdir Alisjahbana (1981) yang mengindikasikan tema emansipasi wanita (Sudjiman, 1988:51-52).

Tema yang dikembangkan melalui latar mengacu pada kesesuaiannya dengan latar dan tokoh. Latar yang tepat akan mempengaruhi tingkah laku dan pikiran tokoh sehingga hal ini juga akan mempengaruhi pemilihan tema. Begitu pula sebaliknya, tema yang telah dipilih akan 
menuntut pemilihan latar dan tokoh yang sesuai.

Tokoh cerita bertujuan untuk menyampaikan tema yang dimaksudkan pengarang. Tema tersebut tidak disampaikan secara langsung, tetapi melalui tingkah laku (verbal dan nonverbal), pikiran dan perasaan, dan berbagai peristiwa yang dialami tokoh.

Alur juga menjadi salah satu unsur yang dapat mengungkapkan tema. Unsur ini memuat tindakan yang dilakukan tokoh dan peristiwa yang dialami tokoh. Hal ini memberikan pemahaman kepada pembaca tentang cerita yang berkaitan dengan tokoh. Oleh karena itu, alur akan menjadi unsur penting dalam menemukan tema sebuah cerita (Nurgiyantoro, 1995:74-75). Kehadiran berbagai unsur intrinsik dalam karya sastra bertujuan membangun cerita. Hal ini pula yang mendukung eksistensi tema. Akan tetapi, tema dan cerita bukanlah hal yang sama. Tema merupakan dasar cerita dan cerita disusun dan dikembangkan berdasarkan tema. Tema berfungsi mengikat pengembangan cerita atau sebaliknya, cerita yang dikisahkan harus mendukung penyampaian tema. Dengan demikian, cerita merupakan sarana untuk menyampaikan tema, makna, atau tujuan penulisan karya tersebut (Nurgiyantoro, 1995:75-77).

\section{METODE PENELITIAN}

Dalam melakukan penelitian ini, langkah awal yang penulis lakukan adalah menelusuri keterangan tentang naskah SCAS. Kegiatan tersebut meliputi menginventarisasikan jumlah naskah dan mendeskripsikan naskah untuk mengetahui kondisi fisiknya. Proses selanjutnya adalah membaca hasil transliterasi yang sudah lebih dulu dilakukan dan menelaah tema pada teks.

Dalam menganalisis tema, metode yang digunakan meliputi penjabaran pola pengembangan tema berdasarkan konsep Panuti Sudjiman dalam Memahami Cerita Rekaan (1988), penganalisisan tema berdasarkan konsep, pemaparan kesesuaian tema dengan genre SCAS yang ditujukan untuk bacaan anak sekolah, dan penjabaran struktur pemersatu tema-tema SCAS.
Paparan kekhasan bahasa dalam SCAS menunjukkan kekhasan teks tersebut. Hal ini pernah diteliti oleh tiga orang ahli. Pertama, Ch. A. van Ophuijsen (1983) dalam bukunya yang berjudul Tata Bahasa Melayu menyebutkan beberapa gejala bahasa Melayu, salah satunya adalah bunyi h dihembuskan kuat sekali dengan bunyi geseran sehingga bunyinya semakin jelas (Ophuijsen, 1983:14-15). Kedua, J. J. de Hollander (1984) dalam bukunya Pedoman Bahasa dan Sastra Melayu, dalam bahasa Melayu Minangkabau, bunyi /e/ diucapkan sebagai /a/ (Hollander, 1984:27). Ketiga, D. Gerth van Wijk (1985) dalam bukunya Tata Bahasa Melayu mengungkapkan gejala, seperti huruf /p/ dan /t/ pada akhir kata sering kurang tegas dalam pengucapannya dan berubah menjadi /b/ (Wijk, 1985:5).

\section{HASIL DAN PEMBAHASAN}

\subsection{Inventarisasi SCAS}

Setelah melakukan penelusuran di sembilan katalogus, untuk sementara SCAS dapat dianggap sebagai naskah tunggal (codex unicus) yang kini tersimpan di PNRI dengan nomor ML 276. Keterangan mengenai naskah ini dimuat dalam katalogus Sutaarga (1972), van Ronkel (1909), dan Behrend (1998). Sutaarga dan van Ronkel menyebut naskah ini dengan judul Buku Sekolah, sedangkan Behrend memberi judul Segala Cerita Anak Sekula, sementara di naskah tertulis Cerita Segala Rupa-rupa akan Dibaca-baca Anak Sekula.

\subsection{Deskripsi SCAS}

Naskah SCAS berukuran $17 \mathrm{~cm} \times 14,5 \mathrm{~cm}$. Teks terdiri dari 33 halaman yang memuat 20 baris per halamannya. SCAS ditulis dalam aksara Jawi berbahasa Melayu dan ditulis dengan tinta berwarna hitam. Akan tetapi, tulisan teks agak sulit dibaca karena tintanya menembus ke halaman berikutnya. Naskah ini sudah mulai rusak karena patah dan berlubang di beberapa bagian. Cap kertas naskah ini berupa gambar singa dalam lingkaran yang bertuliskan Pro Patria Eendragt Maakt Magt. Kertas naskah diperkirakan berasal dari London tahun 1765 atau dari England tahun 1770-1790. Naskah ini disatukan dalam empat kuras, dua di antaranya sudah lepas. 
Teks SCAS terdiri dari tujuh cerita dan setiap cerita memuat kisah yang berbedabeda. Ketujuh cerita tersebut adalah cerita tokoh 'saya' yang masuk ke kandang macan, cerita gembala kerbau yang diserang macan, cerita pemuda berusia empat belas tahun berusaha menaklukkan macan yang mengamuk di desanya, cerita seorang janda yang tinggal bersama anaknya dan temannya beserta cucu yang menumpang diserang macan di rumahnya, cerita seorang tukang kayu yang rajin dan pandai menjadi kaya karena kerja keras dan kejujurannya, cerita anak dari orang kaya yang sangat jahat sehingga ia hidup sengsara, dan cerita yang memuat keterangan tentang kerugian menyabung ayam.

Ada dugaan kuat SCAS ditujukan untuk bacaan anak-anak sekolah di Painan (nama daerah di Sumatra Barat, pusat pemerintahan Kabupaten Pesisir Selatan). Nama daerah Painan tidak hanya muncul di awal teks, tetapi juga muncul di halaman 35 dalam naskah (lampiran hlm. 23). Hal yang menarik dari naskah SCAS adalah angka tahun yang muncul di kolofon dan di halaman 35 (lampiran hlm. 23). Di dalam kolofon, tercantum keterangan naskah ini bertanggal 15 September 1861. Sementara itu, di halaman 35 tercantum tanggal 29 Februari 1862. Angka tahun yang muncul di naskah berbeda dengan angka tahun yang muncul di katalog Sutaarga (1972), van Ronkel (1909), dan Behrend (1998). Sutaarga dan van Ronkel menyebut tanggal 18 September 1861, sedangkan Behrend mengemukakan tahun 1661. Perbedaan keterangan tersebut akan dibahas pada bab II dalam penelitian ini. Walaupun terdapat perbedaan pendapat mengenai tanggal yang tercantum dalam kolofon, kemunculan angka tahun 1861 mengindikasikan pada pertengahan abad ke-19 di Indonesia, khususnya di Sumatera Barat, terdapat bacaan anak-anak yang ditulis dalam aksara Jawi.

Tambahan pula, pada akhir abad ke-19 ada kecenderungan naskah ditulis dan disalin untuk kepentingan pendidikan. Menurut Indra Rukmi, pada tahun 1819 telah berdiri sebuah skriptorium (tempat penyalinan naskah) bernama Algameene Secretaria di Jakarta. Naskah yang disalin di tempat tersebut dipakai oleh pejabat pemerintahan Belanda untuk mempelajari bahasa Melayu. Sebagian naskah tersebut dikirim ke Akademi Delf, tempat pendidikan bagi pemuda- pemuda Belanda yang akan menjadi pegawai pemerintah di HindiaBelanda (Daruninten, 2005:3).

\subsection{Ringkasan Cerita}

SCAS terdiri atas tujuh cerita. Berikut ini ringkasan masing-masing cerita.

\section{Cerita Pertama}

Cerita pertama berkisah tentang seseorang yang masuk ke kandang macan karena ingin berteduh dari hujan yang mendadak turun. Ketika ia berada di dalam kandang, macan tiba-tiba datang dan masuk kandang tersebut. Orang itu sangat ketakutan ketika melihat macan itu matanya menyala-nyala dan mulutnya mengaum. Untungnya, sesaat kemudian dua orang saudaranya dan warga kampung melihat ia terkurung di kandang macan. Mereka berusaha mengeluarkan orang itu dari dalam kandang. Akhirnya, orang itu berhasil ke luar kandang dengan selamat.

Setelah kejadian itu, telinga orang itu sakit apabila mendengar suara. Akan tetapi, penyakitnya tersebut sembuh dengan sendirinya. Kemudian ia menyadari, kejadian buruk yang terjadi padanya merupakan akibat dari kurangnya ia bersyukur kepada Allah atas semua rahmat yang telah ia terima. Selain itu, ia menduakan Allah dengan percaya pada benda-benda yang dapat memberikan kesaktian, seperti keris yang ia miliki. Di akhir cerita, ia bertobat kepada Allah dengan menjual keris yang dikiranya bisa menyelamatkan hidupnya.

\section{Cerita Kedua}

Cerita kedua berkisah tentang gembala kerbau yang diserang macan ketika ia mengembala kerbaunya di padang rumput. Ketika orang itu hampir dimakan macan, kerbaunya menyerang macan agar gembala itu lepas dari cengkeraman macan. Kerbau dan macan itu kemudian berkelahi. Akhirnya, kerbau itu kalah dan berhasil ditaklukkan macan. Melihat hal itu, si gembala menangis sehinggga didengar warga desa. Kemudian warga menangkap macan dan membawanya ke Sumedang. Di sana, kerbau dan macan itu dibiarkan 
berkelahi sampai kerbau mati dicabik macan. Akan tetapi, kerbau itu bisa hidup lagi karena diberi obat oleh dukun.

\section{Cerita Ketiga}

Cerita ketiga memuat kisah seekor macan yang masuk ke negeri Cina pada siang hari. Hal ini membuat seorang pemuda berumur empat belas tahun ingin menangkap macan itu. Ia mengajak empat orang temannya memburu macan itu. Ia membawa keris dan kapak sebagai senjata untuk melawan macan. Lalu, berangkatlah mereka ke sawah, tempat persembunyian macan itu. Ketika melihat macan itu, si pemuda dengan beraninya menyerang macan. Ia menggunakan kapak untuk memukul kepala macan itu, tetapi macan itu tidak mati karena kapaknya tidak tajam. Lalu, ia minta teman-temannya melemparkan keris kepadanya, tetapi mereka melarikan diri karena takut melihat macan itu. Alhasil, pemuda itu harus bertarung melawan macan itu sendirian. Kejadian itu dilihat oleh beberapa orang yang membawa senapan. Mereka datang menolong pemuda itu dari serangan macan. Macan itu akhirnya melepaskan si pemuda karena kesakitan. Pemuda itu terluka parah dan dirawat di rumah sakit selama dua hari. setelah sembuh, pemuda itu diberi hadiah berupa uang sebanyak sepuluh rial dan pakaian kebangsaan oleh raja karena ia telah membunuh macan yang masuk ke negerinya.

\section{Cerita Keempat}

Cerita ini berkisah tentang macan yang masuk ke rumah penduduk. Macan itu membunuh semua penghuni rumah, yaitu Bayang Resida dan anak laki- lakinya, serta Bayang Keyaman dan cucu perempuannya yang menumpang di rumah itu.

\section{Cerita Kelima}

Cerita ini terdiri dari beberapa subcerita. Setiap pergantian subcerita ditandai dengan kalimat pemisah. Subcerita pertama berkisah tentang Mutu Turuna yang berhasil mendapatkan pekerjaan sebagai tukang di dusun sehingga ia bisa mengumpulkan uang untuk membayar hutang dan menghidupi istri serta kedua orang tuanya. Subcerita ini dipisahkan dari cerita keempat dengan kalimat ini ceritara daripada orang miskin boleh jadi kaya. Subbab kedua dipisahkan dari subbab pertama dengan kalimat maka suatu hari ketika waktu orang beranti makan maka Muru Turuna hendak pergi ka warung maka ia lihat di tanah di bawah satu celukada satu buku kecil yang terlalu bagus rupanya. Subbab ini berkisah tentang kejujuran Muru Turuna yang mengembalikan uang yang ia temukan di jalan. Muru Turuna teguh mempertahankan sikapnya walaupun ia hampir dibunuh orang karena ingin merampas uang itu. Subbab ketiga berkisah tentang kerjasama yang dilakukan Muru Turuna dengan seorang Cina. Kerjasama tersebut dirasa mencurigakan karena Muru Turuna harus melakukan transaksi secara sembunyi di malam hari. Hal ini membuat Muru Turun melaporkan kecurigaannya kepada aparat dan meminta menggagalkan transaksi tersebut. Subbab ini dibuka dengan kalimat maka pada satu hari datanglah satu Cina bernama Bang Huwa dari Lasin. Selanjutnya, dikisahkan Muru Turuna berhasil memberantas komplotan berandal yang membuat rusuh di negerinya. Subbab cerita ini dibuka dengan kalimat adapun pada masa itu kebetulan rusuh di tanah Rambang dan barapa sudah dibakar dan beberapa orang sudah dibunuh oleh berandal.

\section{Cerita Keenam}

Cerita keenam ini diawali dengan kalimat pembuka ini ceritera daripada orang kaya bolehnya jadi miskin dan dapat celaka dangan salanya sendiri. Kalimat ini memisahkan cerita kelima dan keenam. Selain itu, terdapat pula kalimat lain yang memisahkan subcerita. Cerita pertama berkisah tentang mas Purtosono dan istrinya, Mesa Jidapura, yang mempunyai anak bernama mas Kortosono. Subcerita kedua mengisahkan mas Kortosono yang bertambah besar dan bertambah jahat pula. Subcerita ini diawali dengan adapun mas Kortosono bertambah umurnya dan bertambah jahatnya. Dikisahkan ia suka minum candu dan menyabung ayam. Ia juga suka menyengsarakan orang, misalnya Sengah Wongso, salah satu pekerja ayahnya, difitnah pencuri benda milik ayahnya, padahal ia yang menaruh benda itu di rumah Sengah Wongso. Sebagai akibat dari perbuatan mas Kortosono 
tersebut, Sengah Wongso diusir dari pulau Jawa selama tiga tahun. Subcerita ketiga berkisah tentang dendam mas Kortosono kepada seorang gadis Cina karena menolak permintaannya. Subcerita ini dimulai dengan adapun mas Kortosono malancong di kampung Cina di negeri Kediri. Subcerita selanjutnya mengisahkan pelarian mas Kortosono dari tanah kelahiranya karena takut tertangkap akibat membunuh ayahnya. Subcerita ini diawali dengan kalimat adapun mas Kortosono dan Sekarono berjalan-jalan pada waktu malam di hutan dan di sawah-sawah menuju negeri Surabaya dan makanannya mereka itu barang apa yang didapat mencuri hampir kampung-kampung.

\section{Cerita Ketujuh}

Cerita ketujuh berisi tentang kerugian menyabung ayam.

\subsection{Kekhasan Bahasa Teks SCAS}

Sebelum kita mengkaji tema dalam SCAS, ada baiknya penulis memaparkan kekhasan bahasa yang ditemukan dalam teks karena setiap naskah memiliki keunikan tersendiri. Hal ini pernah diteliti oleh tiga orang ahli, yaitu Ch. A. van Ophuijsen (1983), J. J. de Hollander (1984), dan D. Gerth van Wijk (1985).

Ch. A. van Ophuijsen (1983) dalam bukunya yang berjudul Tata Bahasa Melayu menyebutkan beberapa gejala bahasa Melayu, salah satunya adalah bunyi $h$ dihembuskan kuat sekali dengan bunyi geseran sehingga bunyinya semakin jelas. Akan tetapi, pada awal kata bunyi ini cenderung dihilangkan. Selain itu, Ophuijsen juga menyebutkan huruf $/ \mathrm{k} /$ pada akhir kata diwakili dengan hamzah (s) (Ophuijsen, 1983:14-15).

Selain Ophuijsen, terdapat pula penelitian yang dilakukan oleh J. J. de Hollander (1984). Menurut Hollander dalam bukunya Pedoman Bahasa dan Sastra Melayu, dalam bahasa Melayu Minangkabau, bunyi /e/ diucapkan sebagai /a/. Bentuk ini muncul secara beraturan di dalam teks (Hollander, 1984:27).

Selanjutnya, D. Gerth van Wijk (1985) dalam bukunya Tata Bahasa Melayu mengungkapkan gejala, seperti huruf /p/ dan /t/ pada akhir kata sering kurang tegas dalam pengucapannya dan berubah menjadi /b/ (Wijk, 1985:5).

Selain keempat gejala dalam uraian sebelumnya, penulis juga menemukan gejala-gejala bahasa lainnya. Berikut uraiannya.

\section{Tabel 1}

Gejala Bahasa dalam Teks SCAS

\begin{tabular}{|c|c|c|}
\hline No. & Rincian & Contoh \\
\hline 1. & $\begin{array}{l}\text { Bunyi h } \\
\text { dihembuskan } \\
\text { kuat sekali } \\
\text { dengan bunyi } \\
\text { geseran sehingga } \\
\text { bunyinya semakin } \\
\text { jelas. Akan tetapi, } \\
\text { pada awal kata } \\
\text { bunyi ini } \\
\text { cenderung } \\
\text { dihilangkan. }\end{array}$ & $\begin{array}{l}\text { Ampir (hlm. } \\
\text { 31) } \\
\text { idupnya (hlm. } \\
40 \text { ) } \\
\text { itung (hlm. } \\
\text { 33) } \\
\text { kasi (hlm. 26) } \\
\text { kaujanan } \\
\text { (hlm.25) } \\
\text { mengadapkan } \\
\text { (hlm. 34) }\end{array}$ \\
\hline 2. & $\begin{array}{l}\text { Pada kata-kata } \\
\text { tertentu, terdapat } \\
\text { penambahan } \\
\text { huruf dan bunyi } \\
\text { /h/ di depan, di } \\
\text { tengah, atau di } \\
\text { belakang kata. } \\
\text { Selain itu, } \\
\text { terdapat pula } \\
\text { sisipan /ha/. }\end{array}$ & $\begin{array}{l}\text { Baharu (hlm. } \\
27) \\
\text { buhaya (hlm. } \\
42 \text { ) } \\
\text { cumah (hlm. } \\
44 \text { ) } \\
\text { hatab (hlm. } \\
28) \\
\text { hayam (hlm. } \\
43 \text { ) }\end{array}$ \\
\hline 3. & $\begin{array}{l}\text { Huruf /p/ dan /t/ } \\
\text { pada akhir kata } \\
\text { sering kurang } \\
\text { tegas dalam } \\
\text { pengucapannya } \\
\text { dan berubah } \\
\text { menjadi /b/. }\end{array}$ & $\begin{array}{l}\text { Ditangkab } \\
\text { (hlm. 26) } \\
\text { Ganab (hlm. } \\
\text { 33) } \\
\text { Harab (hlm. } \\
\text { 32) } \\
\text { mengadab } \\
\text { (hlm. 34) } \\
\text { patub (hlm. } \\
\text { 37) } \\
\text { selengkabnya } \\
\text { (hlm. 27) } \\
\text { tertutub (hlm. } \\
\text { 25) }\end{array}$ \\
\hline 4. & $\begin{array}{l}\text { Huruf /y/ diakhir } \\
\text { kata diikuti } \\
\text { dengan huruf /a/ } \\
\text { sehingga terbaca } \\
\text { [ya] }\end{array}$ & $\begin{array}{l}\text { diya (hlm. } \\
\text { 25) } \\
\text { muliya-muliya } \\
\text { (hlm. 26) } \\
\text { piyara (hlm. } \\
29 \text { ) } \\
\text { sedya (hlm. } \\
45 \text { ) }\end{array}$ \\
\hline
\end{tabular}




\begin{tabular}{|c|c|c|}
\hline 5. & $\begin{array}{l}\text { Huruf / } \mathrm{\eta} / \text { pada } \\
\text { kata-kata tertentu } \\
\text { ditulis huruf /n/ }\end{array}$ & $\begin{array}{l}\text { sembuni } \\
\text { (hlm. 35) }\end{array}$ \\
\hline 6. & $\begin{array}{l}\text { Huruf /k/ pada } \\
\text { akhir kata diwakili } \\
\text { dengan hamzah } \\
\text { (s) }\end{array}$ & $\begin{array}{l}\text { Bawak (hlm. } \\
\text { 27) } \\
\text { bukak (hlm. } \\
\text { 33) } \\
\text { dibukaknya } \\
\text { (hlm. 26) } \\
\text { mintak (hlm. } \\
\text { 32) } \\
\text { purak-purak } \\
\text { (hlm. 34) }\end{array}$ \\
\hline 7. & $\begin{array}{l}\text { Huruf /u/ pada } \\
\text { kata tertentu } \\
\text { dilafalkan /e/ } \\
\text { atau diftong au } \\
\text { pada kata } \\
\text { tertentu } \\
\text { dilafalkan /u/ }\end{array}$ & $\begin{array}{l}\text { gumentar } \\
\text { (hlm. 25) } \\
\text { kuliling (hlm. } \\
\text { 38) } \\
\text { kutika (hlm. } \\
38 \text { ) } \\
\text { mularat (hlm. } \\
45 \text { ) } \\
\text { sudara (hlm. } \\
34)\end{array}$ \\
\hline 8. & $\begin{array}{l}\text { Huruf /g/ } \\
\text { digantikan huruf } \\
\text { /f/ }\end{array}$ & $\begin{array}{l}\text { Astaffirullah } \\
\text { (hlm. 25) }\end{array}$ \\
\hline 9. & $\begin{array}{l}\text { Imbuhan ber- } \\
\text { tidak ditulis } \\
\text { lengkap, huruf /r/ } \\
\text { lesap }\end{array}$ & $\begin{array}{l}\text { Bekelahi } \\
\text { (hlm. 26) }\end{array}$ \\
\hline 10. & $\begin{array}{l}\text { Terdapat satu } \\
\text { kata yang tidak } \\
\text { lazim, yaitu terda } \\
\text { (ادر). Setelah } \\
\text { melakukan } \\
\text { penelusuran, } \\
\text { ditemukan kata } \\
\text { terada (درالد) } \\
\text { 'tiada' dalam } \\
\text { NMNW yang mirip } \\
\text { dengan terda, } \\
\text { tetapi letak huruf } \\
\text { (I)-nya berbeda } \\
\text { (Klinkert, } \\
\text { 1893:258) }\end{array}$ & $\begin{array}{l}\text { terda (hlm. } \\
34)\end{array}$ \\
\hline 11. & $\begin{array}{l}\text { Terdapat variasi } \\
\text { beberapa kata, } \\
\text { misalnya karena, } \\
\text { cerita, dan } \\
\text { berhenti }\end{array}$ & $\begin{array}{l}\text { Karena } \\
\text { Kerna } \\
\text { Kerana } \\
\text { Ceritera } \\
\text { Ceritara } \\
\text { Baranti } \\
\text { Beranti } \\
\text { Berenti }\end{array}$ \\
\hline
\end{tabular}

Selain gejala bahasa yang muncul, kekhasan naskah ini juga ditunjukkan dengan penggunaan kalimat berbeda di awal cerita. Kalimat tersebut berfungsi untuk memisahkan satu cerita dengan cerita lain. Hal itu juga diperlukan sebagai bentuk naratif cerita yang akan disampaikan, seperti halnya cerita anak-anak yang diawali dengan frasa "pada suatu hari". Dalam SCAS, terdapat tujuh cerita utama yang ditandai dengan angka Arab $1-7$, tetapi cerita kelima dan keenam memiliki beberapa subcerita yang akan ditandai dengan huruf $a, b, c, d$, dan seterusnya. Berikut rinciannya.

\section{Tabel 2}

Subcerita dalam SCAS

\begin{tabular}{|c|c|}
\hline Cerita & Kalimat Awal \\
\hline 1 & $\begin{array}{l}\text { Coba dangar tuan-tuan } \\
\text { bagaimana saya hampir dimakan }\end{array}$ \\
\hline
\end{tabular}
hutan (hlm. 25)

\begin{tabular}{cl}
\hline 2 & $\begin{array}{l}\text { Pada satu hari maka adalah satu } \\
\text { orang di tanah Pariangan } \\
\text { mangubalakan diya punya } \\
\text { kerbau di tanah rumput (hlm. } \\
\text { 26) }\end{array}$ \\
\hline 3 & $\begin{array}{l}\text { Ini ceritera dari satu macan } \\
\text { yang dilihat orang di tanah Cina } \\
\text { Tiri kutika tengah hari (hlm. 27) }\end{array}$ \\
\hline 4 & $\begin{array}{l}\text { Ini apa lagi satu ceritara perkara } \\
\text { macan (hlm. 27) }\end{array}$ \\
\hline $5 a$ & $\begin{array}{l}\text { Ini ceritara daripada orang } \\
\text { miskin boleh jadi kaya (hlm. 29) }\end{array}$ \\
\hline 5b & $\begin{array}{l}\text { Maka suatu hari ketika waktu } \\
\text { orang beranti makan (hlm. 30) }\end{array}$ \\
\hline 5c & $\begin{array}{l}\text { Maka pada satu hari datanglah } \\
\text { satu Cina bernama Bang Huwa } \\
\text { dari Lasin (hlm. 34) }\end{array}$ \\
\hline 5d & $\begin{array}{l}\text { Adapun pada masa itu kebetulan } \\
\text { rusuh di tanah Rambang dan } \\
\text { barapa sudah dibakar dan } \\
\text { beberapa orang sudah dibunuh } \\
\text { oleh berandal (hlm. 35) }\end{array}$ \\
\hline 6a & $\begin{array}{l}\text { Ini ceritera daripada orang kaya } \\
\text { bolehnya jadi miskin dan dapat } \\
\text { celaka dangan salanya sendiri } \\
\text { (hlm. 36) }\end{array}$ \\
\hline 6b & $\begin{array}{l}\text { Adapun satu hari mas Kortosono } \\
\text { mengadap bapa(k) ibunya serta } \\
\text { mintak izin akan pergi ka } \\
\text { Surabaya (hlm. 37) }\end{array}$ \\
\hline &
\end{tabular}




\begin{tabular}{cl}
\hline 6c & $\begin{array}{l}\text { Adapun mas Kortosono } \\
\text { bertambah umurnya dan } \\
\text { bertambah jahatnya (hlm. 39) }\end{array}$ \\
\hline 6d & $\begin{array}{l}\text { Maka pada satu hari mas } \\
\text { Purtosono lihat kancing mas dua } \\
\text { puluh biji baju sudah hilang dan } \\
\text { dicari kuliling rumah terda } \\
\text { bertamu juga (hlm. 39) }\end{array}$ \\
\hline 6e & $\begin{array}{l}\text { Adapun pada satu malam mas } \\
\text { Kortosono dan Sekarono duduk } \\
\text { mandi (hlm. 41) }\end{array}$ \\
\hline 7 & $\begin{array}{l}\text { Ini surat akan mencitakan } \\
\text { daripada perkara orang biasa } \\
\text { menyabung ayam atau bertaruh } \\
\text { ayam (hlm. 42) }\end{array}$ \\
\hline
\end{tabular}

Berdasarkan data tersebut, penulis menemukan keteraturan kata dan frase yang digunakan sebagai penanda pergantian ide cerita. Kata yang sering digunakan adalah maka, adapun, ini, dan pada di awal kalimat. Frase yang muncul adalah coba dangar tuan-tuan, pada suatu hari, maka/adapun pada suatu hari/malam, ini ceritera dari/daripada, ini surat akan mencitakan, dan ini apa lagi satu cerita. Frase tersebut ditujukan untuk menarik perhatian pembaca.

Keteraturan ini mengindikasikan pertautan antarcerita. Cerita pertama yang memuat kisah macan dimulai dengan frase coba dangar tuan-tuan yang bertujuan untuk menarik minat pembaca. Cerita kedua dimulai dengan klausa pada satu hari maka adalah satu orang di tanah Pariangan mangubalakan diya punya kerbau di tanah rumput yang menandai kesamaan kisah dengan cerita pertama walaupun kejadiannya berbeda. Cerita ketiga dimulai dengan klausa ini ceritera dari satu macan yang dilihat orang di tanah Cina Tiri kutika tengah hari, hal ini mengindikasikan cerita ini masih memuat kisah yang sama dengan dua cerita sebelumnya, yaitu kisah macan. Begitu pula halnya dengan cerita keempat yang diawali dengan ini apa lagi satu ceritara perkara macan. Kata lagi menegaskan kesamaan kisah dalam cerita keempat dengan cerita-cerita sebelumnya. Akan tetapi, kisah tentang macan tidak lagi muncul pada cerita kelima, keenam, dan ketujuh. Ketiga cerita ini memuat kisah yang dapat dijadikan sebagai ajaran moral, seperti kisah tentang orang miskin menjadi kaya karena bekerja keras (cerita kelima), orang kaya menjadi miskin karena perbuatan jahatnya (cerita keenam), dan dampak buruk menyabung ayam (cerita ketujuh).

\subsection{Analisis Tema Setiap Cerita}

Berikut ini pembahasan analisis tema SCAS sesuai dengan urutan cerita. Tema cerita akan ditampilkan di bagian awal sebagai judul dan akan dijabarkan di dalam analisis.

\section{Dekat dengan Tuhan setelah celaka}

Tema cerita ini adalah kesadaran manusia untuk mendekatkan dirinya pada Tuhan setelah ia lepas dari maut. Hal ini terlihat pada alur cerita dan pikiran tokoh. Hal tersebut dapat dilihat pada kutipan berikut.

Coba dangar tuan-tuan bagaimana saya hampir dimakan macan kapan hari masuk di hutan... saya punya kiralah bagaimana saya punya hal kalau macan mau datang.

Astaffirullah macan datang, satu macan besar seperti kerbau tetapi saya boleh juga cabut saya punya karis di hadapan itu macan. Habis begitu saya serahkan saya punya jiwa sama Tuhan Allah saya hampir mati dari sebab saya punya takut terlalu sangat.

...saya kurang sukur kepada Tuhan Allah yang sudah melapaskan saya di mulut macan. (SCAS:1-2)

Kesadaran tokoh itu semakin jelas terlihat di akhir cerita melalui pikiran tokoh. Hal tersebut ditunjukkan dengan penyerahan diri dan rasa syukur kepada Tuhan. Tokoh juga melakukan perubahan dengan cara menjual keris pusaka miliknya yang dianggap sakti.

\section{Si Lemah vs Si Kuat}

Tema cerita ini adalah perjuangan makhluk yang lemah menghadapi makhluk yang lebih kuat. Hal ini dapat diketahui dari peristiwa yang dialami tokoh, pengembala, yang hampir diterkam macan. Meskipun memiliki kekuasaan dalam banyak hal, manusia tetap tidak bisa melawan kekuatan alam yang besar tanpa senjata. Begitu pula halnya dengan binatang, kerbau yang digembalakan manusia berusaha keras melawan macan yang memiliki kekuatan lebih besar. Hal ini menunjukkan manusia ataupun binatang harus berjuang keras untuk mempertahankan kehidupannya agar tidak ditindas dan dihancurkan makhluk yang lebih kuat. Berikut kutipan peristiwa yang menyiratkan tema ini. 
Maka diya punya kuku diletak sama itu orang punya pinggang yang di balik dirinya tidak jatuh, tetapi ia disembar oleh macan.... Tetapi itu binatang terlalu berani disarang macan yang terda mau tinggal diya punya rampasan (SCAS:3).

\section{Nekat Berbuah Manis}

Tema cerita ini adalah kenekatan yang berdampak positif. Hal ini dapat dilihat dari sikap tokoh yang terburu-buru, tanpa perhitungan, ingin mengalahkan macan yang meresahkan warga kampungnya. Meskipun ia tidak memiliki kemampuan apapun dan tidak mempersiapkan diri dengan maksimal, ia nekat melawan macan itu. Kenekatan ini membuat si pemuda hampir diterkam macan jika ia tidak diselamatkan warga. Akan tetapi, tindakan gegabah ini justru membuat si pemuda mendapat penghargaan dari raja karena dianggap telah mengalahkan macan itu. Hal tersebut dapat dilihat pada kutipan berikut.

Ini ceritera dari satu macan yang dilihat orang di tanah Cina Tiri kutika tengah hari. Maka kabar itu didangar satu bujang baharu empat belas tahun umurnya. Lantas diya ajak diya punya teman empat orang buat pergi memburu itu macan. Maka diya pergi bawak karis dan kapak di sawah di mana itu macan ada tersembuni. ...dan tuan Rasid Nita kasi sama diya itu pembalasan sepuluh rial yang ditentukan Gofur Namin Tamabarang siapa yang bunuh dan dikasi lagi pakaian selengkabnya sama itu bujang (SCAS:3- 5).

\section{Kemalangan yang Tak Terduga}

Tema cerita ini adalah kemalangan yang tak terduga. Kemalangan yang dialami merupakan salah satu bentuk kuasa Tuhan dalam mengatur hidup manusia. Hal inilah yang dialami Bayang Resida dan keluarganya. Ia tentu tidak akan menduga seekor macan masuk ke dalam rumahnya dan mencabik-cabik tubuhnya tanpa ia berkesempatan untuk melakukan perlawanan. Macan itu tiba-tiba masuk dan memorak-porandakan seisi rumah. Masyarakat di sekitar rumah itu tentu tidak pula menyangka tetangga mereka akan mengalami kemalangan seperti itu. Semua sudah takdir Tuhan, tidak ada manusia yang dapat mengelak dari takdir.

Salah satu tanda permainan nasib dalam cerita ini adalah tempat kemunculan macan itu. Ia muncul dari sebuah lubang padahal lubang itu sudah ditutup. Berikut kutipannya.

Lantas bangun sebab tangguhnya satu mencana yang ada di atas hatab rumah itu dan lantas itu macan masuk dari satu lubang yang ada dipaku tempatnya orang itu (SCAS:5).

Setelah masuk ke dalam rumah, macan itu segera memorak-porandakan seisi rumah. Tidak ada satu pun penghuni yang selamat dari terkaman macan dan tidak ada satu orang pun yang berusaha menyelamatkan mereka. Kejadian itu terjadi sangat cepat sehingga tidak dapat dicegah atau diubah.

\section{Kerja Keras dan Jujur Kunci Keberhasilan}

Tema cerita kelima ini adalah kerja keras dan kejujuran sebagai faktor pendukung pencapaian kesuksesan. Kita harus memiliki kedua sifat tersebut karena dengan kerja keras segala tantangan yang menghadang dapat ditaklukkan dan dengan kejujuran kepercayaan dari orang lain akan mudah diperoleh. Hal ini menjadi barometer kesuksesan seseorang. Orang yang jujur dan pekerja keras memiliki etos kerja yang tinggi sehingga segala tantangan dan rintangan dianggap sebagai batu loncatan untuk meningkat prestasi dan memperbaiki taraf kehidupannya, sedangkan orang yang tidak jujur dan malas hanya akan menduduki posisi yang statis.

Tema tersebut dapat dilihat pada alur cerita yang mengisahkan Muru Turuna, seorang tukang kayu, yang harus membayar utang dengan cara bekerja di daerah lain. Sedikit demi sedikit pendapatan yang diperolehnya meningkat karena ia bekerja dengan baik. Selain itu, ia adalah orang yang jujur. Ia tidak mengambil keuntungan untuk dirinya sendiri ketika ia menemukan uang di jalan padahal uang itu jumlahnya sangat banyak. Ia juga tidak ingin berbuat curang ketika seorang Cina memintanya menyelundupkan barang. Tindakan Cina itu segera dilaporkannya kepada pihak yang berwajib karena ia merasa hal itu bukanlah tindakan yang baik. Sebagai hasil dari kejujurannya, Muru Turuna memperoleh kenaikan gaji, kenaikan pangkat, dan kepercayaan dari majikannya dan masyarakat di lingkungannya. Hal ini dapat dilihat pada kutipan berikut. 
Adapun baru tiga atau empat minggu Muru Turuna jadi naik gajinya tuan yang suruh membuat kepada itu sedikit. Ia satu orang terlalu pandai jadi tukang kayu maka tuan itu kasi naik gajinya sampai selapan puluh duit satu hari (SCAS:8).

Kutipan ini menunjukkan kerja keras yang dilakukan oleh Muru Turuna karena dalam tiga atau empat minggu ia sudah menerima kenaikan gaji.

...ada satu buku kecil...dapat di bali(k) sepuluh ribu uang kertas...yang punya uang ini tuan yang kasi pekerjaan kepada saya...maka Muru Turuna lantas terus ka rumahnya tuan lantas diunjuk itu uang dangan buku tempat uang kertas kepada tuan itu... (SCAS:8-9).

Maka pada satu hari datanglah satu Cina Maka kata Bang Huwa, "Kalau Muru Turuna mau tolong barang sedikit saja pada saya..." "Nanti besok malam ada satu perahu nanti berenti di laut terda sampai kalihatan orang dari darat.".. Muru Turuna lantas turun ka darat bari tahu segala hal i(h)wal itu kepada wedana dan wedana suruh bawak perahu tub dan segala orang yang ditangkab itu ke Rambang (SCAS:1415).

Adapun pada masa itu kebetulan rusuh di tanah Rambang Muru Turuna itu juga disuruh panggil karana diya punya beberani dan akal (SCAS:16).

Kutipan ini menunjukkan kejujuran Muru Turuna ketika ia mengembalikan uang yang ditemukannya dan keberaniannya memberitahukan penyelundupan yang akan dilakukan oleh orang Cina yang meminta bantuannya. Setelah peristiwa tersebut, ia diberi kepercayaan untuk mengatasi masalah yang sedang terjadi. Selain jujur, ia juga berani dan mempunyai banyak akal.

Maka karunia oleh Gofur Naminata angkat raden dan nama Suruh Jawah kepada Muru Turuna itu dan jadikan wadono di dalam satu distrik yang besar sekali (SCAS:16).

Sebagai imbalan atas perbuatannya, Muru Turuna diangkat menjadi raden dan dijadikan wedana di suatu daerah. Setelah itu, kehidupan Muru Turuna menjadi lebih baik, ia tidak lagi menjadi tukang kayu miskin.

\section{Siapa yang Menanam, Dia yang Menuai}

Tema cerita ini adalah kita akan memetik hasil dari perbuatan kita. Apabila kita berbuat baik, kita akan mendapatkan manfaat dari kebaikan itu. Begitu pula sebaliknya, apabila kita berbuat jahat, suatu saat nanti kita akan menerima ganjaran atas kejahatan yang dilakukan. Hal inilah yang muncul dalam cerita keenam. Mas Kortosono menerima ganjaran atas perbuatan yang telah dilakukannya. Ia kehilangan orang tuanya, kehidupan yang menyenangkan, orang kepercayaan, dan nyawanya karena tindakan di masa lalu. Ganjaran ini merupakan hasil dari perbuatan jahatnya, misalnya ia memfitnah orang lain karena permintaannya tidak dikabulkan, menyiksa seorang perempuan tua karena ditolak cintanya oleh anak perempuan itu, gemar membeli candu sehingga nekat merampok orang tuanya dan akhirnya membunuh mereka, dan menyengsarakan hidup orang yang telah membantunya melakukan kejahatan. Di akhir cerita, ia sadar semua kesengsaraan yang ia rasakan adalah akibat dari kejahatan yang dilakukannya.

\section{Jangan Berbuat Dosa}

Tema cerita ini adalah peringatan agar selalu menjauhkan diri dari dosa. Manusia merupakan makhluk Tuhan yang tidak pernah luput dari dosa. Oleh karena itu, perlu diingatkan agar tidak berbuat dosa.

Salah satu bentuk dosa yang dilakukan manusia adalah menyabung ayam. Tindakan ini dilarang agama karena mendatangkan kerugian. Di dalam cerita ini dikemukakan bahwa menyabung ayam dapat menimbulkan huru-hara, merusak rumah tangga penyabung atau pihak yang terlibat dalam penyabungan tersebut, membuat orang berani berbuat dosa yang lain seperti membunuh, merampok, dan menipu, serta merusak hubungan kekeluargaan atau persahabatan. Berikut kutipan yang memuat kerugian menyabung ayam.

Pertama, adu hayam itu lawan [per] perintah Allah Ta'ala karana pada perintah Allah itu terda patut orang ingin hartanya orang lain.

Kedua, adu hayam itu jadikan hiru-hara di dalam negeri. Ketiga, adu hayam itu rusakkan rumah tanggah orang.

Kaempat, adu hayam itu jadikan orang berani bunuh. 
Kelima, adu hayam itu datangkan [kecederaan] kecederaan sahabat dan teman-teman (SCAS:29).

Berdasarkan pemaparan tersebut, penulis menemukan tujuh tema dalam SCAS, yaitu keinsafan makhluk Tuhan yang telah lalai dan durhaka, perjuangan makhluk yang lemah menghadapi kekuasaan yang besar, tindakan kurang perhitungan yang menghasilkan kesuksesan, kewaspadaan, kerja keras dan kejujuran sebagai faktor pendukung mencapai kesuksesan, kita akan memetik hasil dari perbuatan kita, dan peringatan agar selalu menjauhkan diri dari dosa. Ketujuh tema dikemas dalam tujuh cerita yang berbeda, yaitu empat cerita berkisah tentang macan, satu cerita tentang tukang kayu yang menjadi kaya, satu cerita tentang orang kaya yang menjadi miskin, dan satu cerita yang berisi kerugian menyabung ayam.

Apabila ditinjau dari SCAS yang ditujukan untuk bacaan anak sekolah, ketujuh tema tersebut dapat mewakili cerita untuk anakanak karena mengandung nilai moral, memberikan pelajaran, dan dikemas dalam cerita yang menarik. Menurut penulis, dengan dibacakannya SCAS pada masa lampau memberikan sumbangan yang luar biasa dalam bidang pendidikan. Mereka diberikan pendidikan moral berupa kesadaran untuk selalu menyembah Tuhan dengan cara melakukan segala perintahNya dan meninggalkan segala laranganNya. Mereka juga diajarkan untuk berani menghadapi tantangan meskipun tidak mempunyai kekuatan atau kekuasaan karena makhluk yang lemah pun bisa mengalahkan makhluk yang lebih kuat. Selain itu, mereka diberikan pemahaman untuk mencapai kesuksesan diperlukan kerja keras dan kejujuran. Kesuksesan juga dapat diraih dengan modal nekat meskipun tindakan ini berisiko. Mereka juga diajarkan untuk bisa menerima kemalangan yang tak terduga datangnya dengan baik. Mereka harus menerima hikmah dari kemalangan yang dialaminya dan menjadikan hal itu sebagai pemicu untuk bangkit dan melanjutkan perjuangan.

Pelajaran-pelajaran inilah yang ditampilkan sehingga SCAS dapat dimasukkan sebagai salah satu bahan ajar di masa lampau dan masih dapat digunakan pada masa sekarang, meskipun cerita-cerita yang terkandung di dalamnya sudah tersimpan beberapa abad.

Bagian ini menyajikan hasil penelitian dan pembahasannya sesuai dengan masalah, tujuan penelitian, dan teori yang digunakan.

\section{SIMPULAN}

Segala Cerita Anak Sekula (SCAS) adalah salah satu naskah yang berbentuk hikayat. Naskah ini merupakan bacaan anak-anak sekolah di daerah Painan, Sumatera Barat. Naskah ini bertanggal 15 September 1861. Tanggal yang tercantum dalam kolofon tersebut dimunculkan berbeda-beda dalam tiga katalog: Sutaarga (1972) dan van Ronkel (1909) menyebut tanggal 18 September 1861, sedangkan Behrend (1998) menyebut tahun 1661. Setelah melakukan perbandingan dengan kolofon, dapat dibuktikan bahwa naskah ini berangka tahun 15 September 1861. Hal ini mengindikasikan pada pertengahan abad 19 telah dikenal sistem pendidikan berupa sekolah di Sumatera Barat, khususnya Painan.

Selain nama kota Painan yang disebutkan dalam SCAS, terdapat pula gejala bahasa yang mempertegaskan hubungan naskah dengan nama tersebut (merujuk pada daerah Minangkabau), yaitu munculnya kosakata bahasa Minang seperti mintak, selapan, rabah, dan manang. Akan tetapi, nama daerah di Minangkabau hanya disebut di awal saja, di dalam cerita namanama yang muncul adalah nama daerah di pulau Jawa, seperti Pariangan, Sumedang, Surabaya, Jogjakarta, Tuban, Kediri, Surakarta, Rembang, dan Kidul.

Sebagai peneliti, salah satu hal penting yang perlu ditelusuri sebelum melakukan analisis terhadap teks adalah kekhasan bahasa yang muncul dalam teks tersebut. Ada beberapa hal yang berbeda dengan bahasa Indonesia. Perbedaan inilah yang perlu dipaparkan agar pembaca atau peneliti terbantu dalam menggali isi dari teks.

Jika kita lihat ketujuh cerita dalam SCAS, setiap bagian memuat dengan tema yang berbeda-beda, yaitu:

1. dekat dengan Tuhan setelah celaka,

2. si lemah vs si kuat, 
3. nekat berbuah manis,

4. kemalangan yang tak terduga,

5. kerja keras dan jujur adalah kunci keberhasilan,

6. siapa yang menanam, dia yang menuai,

7. jangan berbuat dosa.

Berdasarkan hal itu, ketujuh tema tersebut cocok dijadikan bahan ajar untuk anak sekolah karena mengandung nilai moral, memberikan pelajaran, dan dikemas dalam cerita yang menarik. Menurut penulis, dengan dibacakannya SCAS pada masa lampau memberikan sumbangan yang luar biasa dalam bidang pendidikan. Mereka diberikan pendidikan moral berupa kesadaran untuk selalu menyembah Tuhan dengan cara melakukan segala perintahNya dan meninggalkan segala laranganNya. Mereka juga diajarkan untuk berani menghadapi tantangan meskipun tidak mempunyai kekuatan atau kekuasaan karena makhluk yang lemah pun bisa mengalahkan makhluk yang lebih kuat. Selain itu, mereka diberikan pemahaman untuk mencapai kesuksesan diperlukan kerja keras dan kejujuran. Kesuksesan juga dapat diraih dengan modal nekat meskipun tindakan ini berisiko. Mereka juga diajarkan untuk bisa menerima kemalangan yang tak terduga datangnya dengan baik. Mereka harus menerima hikmah dari kemalangan yang dialaminya dan menjadikan hal itu sebagai pemicu untuk bangkit dan melanjutkan perjuangan. Pelajaranpelajaran inilah yang ditampilkan sehingga SCAS dapat dimasukkan sebagai salah satu bahan ajar di masa lampau dan masih dapat digunakan pada masa sekarang, meskipun cerita- cerita yang terkandung di dalamnya sudah tersimpan beberapa abad.

\section{DAFTAR PUSTAKA}

Behrend, T. E. (peny.). (1998). Katalog Induk Naskah-naskah Nusantara Jilid 4 Perpustakaan Nasional Republik Indonesia. Jakarta: Yayasan Obor Indonesia, Ecole Francaise D'extreme Orient.

Daruninten, Chitra. (2005). Syair HikmatHikmat IImu: Suntingan Teks dan Latar Belakang Penyalinan Naskah. Skripsi. Depok: FIB UI.
Hollander, J. J. de. 1984. Pedoman Bahasa dan Sastra Melayu seri ILDEP oleh T. W. Kamil (penj.) Jakarta: Balai Pustaka.

Ikram, Achadiati. (1997). Filologia Nusantara. Jakarta: Pustaka Jaya.

Klinkert, H. C. Nieuw Maleisch-Nederlands Woordenboek met Arabisch Karakter. Leiden.

Loir, Henri Chambert dan Oman Fathurahman. (1999). Khazanah Naskah: Panduan Koleksi Naskahnaskah Indonesia Sedunia. Jakarta: Yayasan Obor Indonesia.

Mulyadi, Sri R. W. (1994). "Kodikologi Melayu di Indonesia," dalam Lembar Sastra Edisi Khusus no. 24. Depok: Fakultas Sastra UI.

Nurgiyanto, Burhan. (1995). Teori Pengkajian Fiksi. Yogyakarta: Gajah Mada University Press.

Ophuijsen, C. A. van. (1983). Tata Bahasa Melayu seri ILDEP(terj. T. W. Kamil). Jakarta: Djambatan.

Ronkel, S. van. (1909). Catalogus der Maleische Handschriften in het Museum van het Bataviaasch Genootschap van Kunsten en Wetenschappen, VBG jilid LVII, Albrecht \& co dan nm. Nijhoff.

Sudjiman, Panuti. (1988). Memahami Cerita Rekaan. Jakarta: Pustaka Jaya.

Sutaarga, Amir dkk. (1972). Katalogus Koleksi Naskah Melayu Museum Pusat Dep.P \& K. Jakarta: Dirjen Kebudayaan.

Wijk, D. Gerth van. (1985). Tata Bahasa Melayu seri ILDEP oleh T. W. Kamil (penj.). Jakarta: Djambatan. 